\title{
PENGARUH FEE AUDIT, UKURAN PERUSAHAAN, AUDIT TENURE TERHADAP KUALITAS AUDIT (STUDI EMPIRIS PADA PERUSAHAAN MANUFAKTUR YANG TERDAPAT DI BURSA EFEK INDONESIA PERIODE TAHUN 2014-2018 )
}

\section{Galih Chandra Kirana}

M. Arif Assafiq

chandra.galih13@gmail.com, m.arifassafiq@gmail.com

\section{Fakultas Ekonomi dan Bisnis - Program Studi Akuntansi Universitas Satya Negara Indonesia}

\begin{abstract}
This research examines the influence of auditfee, company size, and audit tenure of audit Quallitas. The population in the study is a manufacturing company registered on IDX in 2014-2018 which is accessed through the IDX official website, which is www.idx.co.id. The sampling method used in this study was purposive sampling, where the sample was taken from a population of 166 and subsequently resulted in samples of 310 observations. While the analytical method used in this hypothesis test is a regression analysis of logistic, using SPSS application version 2.6.

The results of a partial study proved that the audit fee and audit tenure significantly affect the quality of the audit, whereas for the company size itself has no significant effect on the audit quality. This significant relationship is positively valuable which means if the independent variable is increased then the dependent variable also increases as well as vice versa.
\end{abstract}

Keywords: Audit fee, Company size, Audit tenure, Audit quality

Jurnal Ilmiah Akuntansi dan Ekonomi Volume. 6 Nomor. 1, Februari 2021 Hal. 106 


\section{PENDAHULUAN}

Akuntan publik atau auditor independen dalam tugasnya mengaudit perusahaan klien memiliki posisi yang strategis sebagai pihak ketiga dalam lingkungan perusahaan klien yakni ketika akuntan publik mengemban tugas dan tanggung jawab dari manajemen (Agen) untuk mengaudit laporan keuangan perusahaan yang dikelolanya. Dalam hal ini manajemen ingin supaya kinerjanya terlihat selalu baik dimata pihak eksternal perusahaan terutama pemilik (prinsipal). Akan tetapi disisi lain, pemilik (prinsipal) menginginkan supaya auditor melaporkan dengan sejujurnya keadaan yang ada pada perusahaan yang telah dibiayainya. Kepercayaan yang besar dari pemakai laporan keuangan auditan dan jasa lainnya yang diberikan oleh akuntan publik inilah yang akhirnya mengharuskan akuntan publik memperhatikan kualitas audit yang dihasilkannya. Adapun pertanyaan dari masyarakat tentang kualitas audit yang dihasilkan oleh akuntan publik semakin besar setelah terjadi banyak skandal yang melibatkan akuntan publik baik diluar negeri maupun didalam negeri.

Kualitas audit ini menjadi penting karena dengan kualitas audit yang tinggi maka akan dihasilkan laporan keuangan yang dapat dipercaya sebagai dasar pengambilan keputusan. Selain itu adanya kekhwatiran akan merebaknya skandal keuangan, dapat mengikis kepercayaan publik terhadap laporan keuangan auditan dan profesi akuntan publik.

\section{Rumusan Masalah}

1. Apakah Fee audit berpengaruh terhadap kualitas audit?

2. Apakah Ukuran perusahaan berpengaruh terhadap kualitas audit?

3. Apakah audit tenure berpengaruh terhadap kualitas audit?

\section{LANDASAN TEORI}

\section{Teori Agensi}

Konsep teori agensi menurut Anthony dan Govindrajan (2005:269) adalah sebagai berikut :

"hubungan agensi ada ketika salah satu pihak (principal) menyewa pihak lain (agen) untuk melaksanakan suatu jasa dan dalam melakukan hal itu mendelegasikan wewenang untuk membuat keputusan kepada agen tersebut."

Fee Audit

Fee audit menurut Mulyadi (2016:63-64) yaitu :

"Audit fee merupakan fee yang diterima oleh akuntan public setelah melaksanakan jasa auditnya, besarnya tergantung dari resiko penugasan kompleksitas jasa tersebut, struktur biaya KAP yang bersangkutan, anggota KAP tidak diperkenankan mendapatkan 
klien dengan cara menawarkan fee yang dapat merusak cara profesi."

Fee audit diproksikan dengan menggunakan logaritma natural dari data atas akun professional fees. Dasar pengambilan keputusan ini adalah belum tersedianya data tentang fee audit dikarenakan pengungkapan data tentang fee audit di Indonesia masih berupa voluntary disclosure, sehingga belum banyak perusahaan yang mencantumkan data tersebut di dalam annual report.

\section{Fee audit $=$ Ln Professional fees}

\section{Ukuran Perusahaan}

Menurut Hartono (2015:254) menyatakan Ukuran perusahaan adalah:

"Ukuran perusahaan adalah besar kecilnya perusahaan dapat diukur dengan total aktiva/besar harta perusahaan dengan menggunakan perhitungan nilai logaritma total aktiva”

\section{Ukuran Perusahaan $=$ Ln Total Aset}

\section{Audit Tenure}

Audit tenure Suhaib Aamir et all (2011:6) adalah sebagai berikut ; "Audit tenure is defined as the audit firm's (auditor's) total duration to hold their certain or the number of consecutive years that the audit firm (auditor) has audited it's certain client. Tenure"

Variabel audit tenure ini dilihat dari laporan keuangan auditan klien selama 5 tahun berturut-turut yakni mulai dari tahun 2014 sampai tahun 2018. Ketentuan mengenai Audit Tenure telah di jelaskan dalam Keputusan Mentri Keuangan Republik indinesia Nomer 359/KMK.06/2003 pasal 2. Variabel audit tenure ini diukur dengan menghitung jangka waktu penugasan KAP di suatu perusahaan yang sama (dalam

\section{Kualitas Audit} satuan tahun).

Menurut Mulyadi (2014:9) kualitas audit di definisikan sebagai berikut:

"Suatu proses sistematik untuk memperoleh dan mengevaluasi bukti secara obyektif mengenai pernyataanpernyataan tentang kegiatan dan kejadian ekonomis, dengan tujuan untuk menetapkan tingkat kesesuaian antara pernyataan-pernyataan tersebut dengan kriteria yang telah ditetapkan serta penyampaian hasil-hasil kepada pemakai yang berkepentingan." 
Dalam penelitian ini kualitas audit diproksi menggunakan variabel dummy dengan memberikan kode 1 dan 0 terhadap perusahaan sampel dengan melihat ukuran Kantor Akuntan Publik yang mengaudit perusahaan tersebut. Kode 1 untuk perusahaan yang diaudit oleh KAP Big Four dan kode 0 untuk perusahaan yang diaudit oleh KAP Non Big Four.

\section{METODOLOGI PENELITIAN}

Penelitian ini berbentuk penelitian kuantitatif yaitu penelitian yang melihat hubungan variabel terhadap objek yang diteliti, lebih bersifat sebab dan akibat sehingga dalam penelitian ini ada variabel dependen dan variabel independen berupa angka-angka dan analisis menggunakan statistik. Penelitian ini akan dilakukan dengan menggunakan tiga variabel utama yaitu fee audit, ukuran perusahaan, dan audit tenure. Analisis hasil penelitian akan dilakukan dengan menggunakan metode analsis regresi logistik. Data yang digunakan dalam penelitian ini adalah data sekunder yang bersifat kuantitatif mengenai laporan keuangan perusahaan. Adapun sumber data pada penelitian ini diperoleh dari situs resmi Indonesia Stock Exchange www.idx.co.id.

\section{Populasi}

Populasi dalam penelitian ini perusahaan manufaktur yang terdaftar di Bursa Efek Indonesia (BEI) pada tahun 2014 hingga 2018.

\section{Sampel}

Sampel terdiri dari atas sejumlah perusahaan yang dipilih dari populasi .Dalam penelitian ini ada 62 perusahaan dan menggunakan teknik purposive sampling.

\section{Hipotesis \\ Pengaruh Fee audit terhadap Kualitas Audit}

Peneliti yang dilakukan oleh Ninik Adriani (2017) mengatakan bahwa Salah satu faktor eksternal yang mempengaruhi kualitas audit adalah fee audit. Dalam hal ini, diasumsikan bahwa auditor yang berkualitas lebih tinggi akan mengenakan fee audit yang lebih tinggi pula. Hal ini disebabkan karena fee audit yang lebih tinggi akan merencanakan audit kualitas yang lebih tinggi dibandingkan dengan fee audit yang lebih rendah.

Penelitian yang dilakukan Rifki Ramdani (2017) yang menyatakan bahwa hasil dalam penelitiannya tidak signifikan dan tidak sesuai dengan logika penyusunan hipotesis dikarenakan perusahaan yang memberikan audit fee tidak berpengaruh terhadap kualitas audit dikarenakan audit fee

Jurnal Ilmiah Akuntansi dan Ekonomi Volume. 6 Nomor. 1, Februari 2021 Hal. 109 
tidak bisa memprediksi bagus atau tidaknya kualitas audit. Kualitas audit dilihat dari seorang auditor apakah mempunyai sikap independen atau tidak jadi bukan dilihat seberapa besarnya perusahaan memberikan fee audit.

Berdasarkan uraian diatas maka hipotesis yang diturunkan adalah :

Ho1 :Fee audit Tidak berpengaruh terhadap Kualitas audit

Ha1 :Fee audit berpengaruh terhadap Kualitas audit

\section{Pengaruh Ukuran Perusahaan terhadap Kualitas Audit}

Pemilik tidak akan mampu mengelola sendiri secara langsung perusahaannya ketika cakupan usaha dan perusahaan semakin besar (Pujiningsih, 2011 dalam Paramita dan Latrini (2015). O'Brien dan Bhushan (1990) dalam Febriyanti dan Mertha (2014) menyatakan perusahaan kecil memiliki informasi dengan sistem pengawasan yang lemah, dan kurang diperhatikan oleh pemegang sahamnya, sehingga perusahaan ini akan mengasilkan audit yang berkualitas karena peningkatan kualitas audit akan lebih terlihat pada perusahaan kecil. Perusahaan besar dianggap memiliki manajemen yang berpengalaman dengan sistem pengendalian intern yang baik sehingga perusahaan besar akan menghasilkan audit yang lebih berkualitas dibandingkan perusahaan kecil (Fernado et al., 2010 dalam Febriyanti dan Mertha (2014)). Watts dan Zimmerman (1986 dalam Paramita dan Latrini 2015) menyatakan semakin besar perusahaan, semakin meningkat pula agency cost yang terjadi. Sehingga disimpulkan ukuran perusahaan berpengaruh positif pada kualitas audit. Febriyanti dan Mertha (2014) membuktikan bahwa ukuran perusahaan berpengaruh positif dan signifikan terhadap kualitas audit.

Ria Rizki Andrina (2017) yang menyatakan bahwa Besar kecilnya perusahaan belum tentu memiliki manajemen yang berpengalaman dan sistem pengendalian intern yang baik untuk menghasilkan audit yang lebih berkualitas dibandingkan perusahaan kecil. Kemungkinan perusahaan besar yang melaporkan laba dengan tujuan untuk menarik kepercayaan investor. Sehingga dari penelitian ini membuktikan bahwa ukuran perusahaan tidak berpengaruh terhadap kualitas audit.

Berdasarkan uraian diatas maka hipotesis yang diturunkan adalah :

Ho2 :Ukuran perusahaan tidak berpengaruh terhadap kualitas audit

Ha2 :Ukuran perusahaan berpengaruh terhadap kualitas audit

Pengaruh Audit Tenure terhadap Kualitas Audit.

Khairunisa (2015) dalam penelitiannya menunjukan bahwa audit tenure berpengaruh positif terhadap kalitas audit dikarenakan Tenur audit adalah lamanya waktu auditor dalam melakukan pemeriksaan terhadap suatu unit/unit usaha/perusahaan atau instansi. Jika pemeriksaan dilakukan semakin lama maka kualitas auditnnya semakin rendah karna

Jurnal Ilmiah Akuntansi dan Ekonomi Volume. 6 Nomor. 1, Februari 2021 Hal. 110 
independensi auditor semakin lemah. Independensi auditor merupakan dasar dari seorang akuntan.

Umi Salamah (2019) dalam penelitiannya menunjukan bahwa audit tenure tidak berpengaruh terhadap kalitas audit dikarenakan masa perikatan audit bukan patokan bahwa hasil audit akan berkualitas. Lamanya masa perikatan audit seharusnya Kantor Akuntan Publik lebih mengerti kondisi perusahaan klien sehingga tahu jika klien ingin memanipulasi laporan keuangan, tetapi karena masa perikatan yang lama juga Kantor Akuntan Publik (KAP) merasa percaya dengan klien sehingga tidak mengembangkan strategi prosedur audit yang digunakan dan menurunkan kualitas audit.

Berdasarkan uraian diatas maka hipotesis yang diturunkan adalah :

Ho3 :Audit tenure tidak berpengaruh terhdap kualitas audit

Ha3 :Audit tenure berpengaruh terhadap kualitas audit

\section{METODE PENGUJIAN DATA}

\section{Analisis Statistik Logistik}

Statistik deskriptif digunakan untuk memberikan deskripsi suatu data yang dilihat dari rata-rata (mean), standar deviasi (standard deviation), dan maksimum minimum. Mean digunakan untuk memperkirakan besar rata-rata populasi yang diperkirakan dari sampel. Standar deviasi digunakan untuk menilai dispersi rata rata dari sampel. Maksimum-minimum digunakan untuk melihat nilai minimum dan maksimum dari populasi. Statistik deskriptif merupakan gambaran atau deskripsi suatu data yang dilihat dari nilai rata-rata, standar deviasi dan maksimum serta minimum.Ghozali (2016:19).

\section{Menilai Model Fit (Overall Fit Model)}

Langkah pertama adalah menilai overall fit model terhadap data. Beberapa test statistik diberikan untuk menilai hal ini. Hipotesis untuk menilai model fit adalah:

H0 : Model yang dihipotesiskan fit dengan data

HA : Model yang dihipotesiskan tidak fit dengan data

Dari hipotesis ini, agar model fit dengan data maka harus diterima. Statistik yang digunakan berdasarkan Likelihood. Likelihood L dari model adalah probabilitas bahwa model yang dihipotesiskan menggambarkan data input. Adanya pengurangan nilai anatara nilai awal -2LogL dengan nilai -2LogL pada langkah berikutnya menunjukan mengambarkan data input. Adanya pengurangan nilai antar nilai awal -2LogL dengan nilai - 2LogL. Pada langkah berikutnya menunjukan bahwa model yang dihipotesiskan fit dengan data. Penemuan likelihood (-2LogL) menunjukkan model regresi yang lebih baik atau dengan kata lain model yang dihipotesiskan fit dengan data (Ghozali, 2011:340).

\section{Menguji Kelayakan Model Regresi}

Kelayakan model regresi dinilai dengan menggunakan Hosmer and

Jurnal Ilmiah Akuntansi dan Ekonomi Volume. 6 Nomor. 1, Februari 2021 Hal. 111 
Lemeshow's Goodness of Fit Test. Hosmer and Lemeshow's Goodness of Fit Test menguji hipotesis nol bahwa data empiris cocok atau sesuai dengan model (tidak ada perbedaan antara model dengan data sehingga model dapat dikatakan fit). Jika nilai Hosmer and Lemeshow's Go odness of Fit Test statistics sama dengan atau kurang dari 0,05, maka hipotesis nol ditolak yang berarti ada perbedaan signifikan antara model dengan nilai observasinya sehingga Goodness fit model tidak baik karena model tidak dapat memprediksi nilai observasinya. Jika nilai statistik Hosmer and Lemeshow's Goodness of Fit Test lebih besar dari 0,05, maka hipotesis nol tidak dapat ditolak dan berarti model mampu memprediksi nilai observasinya atau dapat dikatakan model dapat diterima karena cocok dengan data observasinya (Ghozali, 2011:345).

\section{Koefisien determinasi (Nagelkerke $R$ Square)}

Koefisien determinasi digunakan untuk mengetahui seberapa besar variabilitas variabel - variabel independen mampu memperjelas variabilitas variabel dependen. Besarnya nilai koefisien determinasi pada model regresi logistik ditunjukkan oleh nilai Nagelkerke R Square.

Koefesien determinasi (Nagelkerke R Square) adalah modifikasi dari koefisien Cox dan Snell's R Square yang merupakan dari ukuran yang mencoba meniru regresi berganda yang didasarkan pada teknik estimasi likelihood dengan nilai maksimum kurang dari 1 (satu) sehingga sulit diinterprestasikan. Nagelkerke R Square merupakan modifikasi dari koefisien Cox dan Snell untuk memastikan bahwa nilainya bervariasi dari 0 (nol) sampai 1 (satu). Hal ini dilakukan dengan cara membagi nilai Cox dan Snell's R Square pada regresi berganda dengan nilai maksimumnya. Nilai yang kecil atau yang mendekati nol menunjukkan bahwa kemampuan variabel-variabel independen dalam menjelaskan variasi variabel dependen sangat terbatas. Sedangkan nilai yang mendekati nilai satu menunjukkan bahwa variabel independen dapat menjelaskan hampir semua informasi yang dibutuhkan dalam memprediksi variabel dependen (Ghozali, 2016:329)

\section{Matriks klasifikasi}

Matrik klasifikasi menunjukkan kekuatan prediksi dari model regresi untuk memprediksi kemungkinan perusahaan dalam membuat keputusan kualitas audit dari KAP Big Four dan Non Big Four (Rifki Ramadani, 2015).

\section{Model regresi linear yang terbentuk}

Analisis yang digunakan dalam penelitian ini adalah analisis regresi logistik (logistic regression) yaitu dengan melihat pengaruh fee audit, ukuran perusahaan dan audit tenure terhadap kualitas audit pada perusahaan jasa di Bursa Efek Indonesia (BEI) yang dilihat pada tabel Variabel In The Equaton . Menurut Winarno (2011) adalah model regresi yang digunakan untuk menganalisis variabel dependen dengan kemungkinan diantara 0 dan 1. Model linier regresi logistik (logistic regression) yang terbentuk dalam penelitian ini adalah sebagai berikut:

1. Model regresi logistik berpengaruh secara parsial

Model regresi yang digunakan dalam penelitian ini adalah sebagai berikut:

Jurnal Ilmiah Akuntansi dan Ekonomi Volume. 6 Nomor. 1, Februari 2021 Hal. 112 


\begin{tabular}{ll}
\hline \multicolumn{2}{c}{ Logit_KA $=\alpha+\beta 1 \times 1+\beta 2 \times 2+\beta 3 \times 3+e$} \\
Keterangan : & \\
Logit KA & : Kualitas audit \\
A & : Konstanta \\
X1 & : Fee Audit \\
X2 & : Ukuran Perusahaan Klien \\
X3 & : Audit Tenure \\
$\beta$ 1-3 & : Koefisien Regresi \\
e & : Eror
\end{tabular}

ANALISIS DAN PEMBAHASAN

\section{Analisis statistik}

Data yang digunakan dalam penelitian ini adalah data yang diambil dari hasil laporan keuangan perusahaan manufaktur yang terdaftar di Bursa Efek Indonesia pada tahun 2014-2018 dan yang sudah lulus dari metode purposive sampling yang dilakukan peneliti. Statistik deskriptif masing-masing variabel dapat dilihat dalam table berikut ini :

\section{Descriptive Statistics}

\begin{tabular}{|l|r|r|r|r|r|}
\hline & N & Minimum & Maximum & \multicolumn{1}{c|}{ Mean } & Std. Deviation \\
\hline Kualitas audit & 310 & 0 & 1 &, 45 &, 498 \\
\hline Fee audit & 310 & 17,76 & 28,97 & 22,2771 & 1,93341 \\
\hline ukuran perusahaan & 310 & 25,46 & 33,47 & 28,6127 & 1,70589 \\
\hline audit tenur & 310 & 1 & 5 & 2,46 & 1,369 \\
\hline Valid N (listwise) & 310 & & & & \\
\hline
\end{tabular}

Sumber : Hasil Penelitian, Data diolah 2020

Tabel tersebut menggambarkan deskripsi variabel-variabel secara statisik dalam penelitian ini. Minimum adalah nilai terkecil dari suatu rangkaian pengamatan, maksimum adalah nilai terbesar dari suatu pengamatan, mean (ratarata) adalah hasil penjumlahan nilai seluruh data dibagi dengan banyaknya data, sementara standar deviasi adalah akar dari jumlah kuadrat dari selisih nilai data dengan rata-rata dibagi dengan banyaknya data, range adalah selisih dari nilai tertinggi dan nilai terendah, dan variance adalah banyaknya variasi nilai.

\section{Menilai Model Fit (Overall Fit Model)}

Penilaian keseluruhan model dilakukan dengan membandingkan nilai antara - 2Log Likelihood pada awal (Block Number $=0$ ), dimana hanya memasukkan konstanta dengan nilai -2Log Likelihood pada akhir (Block Number $=1$ ), dimana model memasukkan konstanta dan variabel bebas. Dalam hal ini digunakan uji nilai model fit (overall model fit test). Pada uji nilai model fit (overall model fit test) dapat dilihat pada tabel berikut ini : 


\section{Iteration History ${ }^{\mathrm{a}, \mathrm{b}, \mathrm{c}}$}

\begin{tabular}{|l|l|rr|}
\hline \multicolumn{2}{|l|}{ Iteration } & \multicolumn{2}{|c|}{ Coefficients } \\
\cline { 3 - 4 } Step 0 & 1 & -2 Log likelihood & Constant \\
\cline { 2 - 4 } & 2 & 426,015 &,- 219 \\
\hline a. Constant is included in the model. &,- 220 \\
\hline b. Initial -2 Log Likelihood: 426,015 \\
\hline c. $\begin{array}{l}\text { Estimation terminated at iteration number 2 because parameter } \\
\text { estimates changed by less than ,001. }\end{array}$ \\
\hline
\end{tabular}

(Sumber : Hasil Penelitian, Data diolah 2020)

\begin{tabular}{|c|c|c|c|c|c|c|}
\hline \multicolumn{7}{|c|}{ Iteration History $^{\mathrm{a}, \mathrm{b}, \mathrm{c}, \mathrm{d}}$} \\
\hline & & \multirow[b]{2}{*}{$\begin{array}{l}-2 \log \\
\text { likelihood }\end{array}$} & \multicolumn{4}{|c|}{ Coefficients } \\
\hline \multicolumn{2}{|c|}{ Iteration } & & Constant & Fee audit & $\begin{array}{c}\text { ukuran } \\
\text { perusahaan }\end{array}$ & audit tenur \\
\hline \multirow[t]{6}{*}{ Step 1} & 1 & 299,251 & $-15,189$ &, 477 &, 139 &, 143 \\
\hline & 2 & 285,055 & $-21,515$ & ,778 &, 120 & 196 \\
\hline & 3 & 283,984 & $-23,796$ & ,895 & 106 & 214 \\
\hline & 4 & 283,975 & $-24,043$ & ,908 & 105 &, 216 \\
\hline & 5 & 283,975 & $-24,045$ & 908 &, 105 & ,216 \\
\hline & 6 & 283,975 & $-24,045$ & ,908 &, 105 &, 216 \\
\hline \multicolumn{7}{|c|}{ a. Method: Enter } \\
\hline \multicolumn{7}{|c|}{ b. Constant is included in the model. } \\
\hline \multicolumn{7}{|c|}{ c. Initial -2 Log Likelihood: 426,015 } \\
\hline \multicolumn{7}{|c|}{$\begin{array}{l}\text { d. Estimation terminated at iteration number } 6 \text { because parameter estimates } \\
\text { changed by less than }, 001 \text {. }\end{array}$} \\
\hline
\end{tabular}

(Sumber : Hasil Penelitian, Data diolah 2020)

Nilai -2Log Likelihood awal adalah sebesar 426,015 dan setelah dimasukkan keempat variabel independen, maka nilai -2Log Likelihood akhir mengalami penurunan menjadi sebesar 283,975. Penurunan nilai -2Log Likelihood ini menunjukkan model regresi yang baik atau dengan kata lain model yang dihipotesiskan fit dengan data (Ghozali, 2016:328).

\section{Menguji Kelayakan Model Regresi}

Menilai kelayakan model regresi. Dari tampilan tabel Hosmer and Lemeshow Test ditunjukkan bahwa besarnya nilai statistik Hosmer and Lemeshow Test sebesar 10,419 dengan probabilitas signifikansi 0,237 dimana $0,237>0,05$ maka hipotesis nol tidak dapat ditolak atau Ho diterima. Hal ini berarti model regresi yang dipergunakan dalam penelitian ini layak dipakai untuk analisis selanjutnya.

Jurnal Ilmiah Akuntansi dan Ekonomi Volume. 6 Nomor. 1, Februari 2021 Hal. 114 


\section{Hosmer and Lemeshow Test}

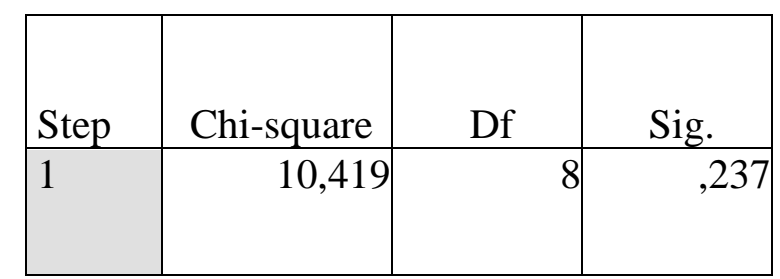

(Sumber : Hasil Penelitian, Data diolah 2020)

\section{Koefisien determinasi (Nagelkerke $R$ Square)}

Hasil uji koefisien determinasi untuk melihat seberapa besar pengaruhnya dapat dilihat pada Tabel Model Summary hasil perhitungan dengan menggunakan Statistical Program for Social Science (SPSS) yang dikalikan $100 \%$, seperti terlihat pada tabel berikut ini :

\section{Hasil pengujian Negelkerke R Square}

\begin{tabular}{|l|c|c|c|}
\hline \multicolumn{4}{|c|}{ Model Summary } \\
\hline Step & $\begin{array}{c}-2 \text { Log } \\
\text { likelihood }\end{array}$ & $\begin{array}{c}\text { Cox \& Snell } \\
\text { R Square }\end{array}$ & $\begin{array}{c}\text { Nagelkerke R } \\
\text { Square }\end{array}$ \\
\hline 1 & $283,975^{\mathrm{a}}$ &, 368 &, 492 \\
\hline
\end{tabular}

a. Estimation terminated at iteration number 6 because parameter estimates changed by less than , 001 .

(Sumber : Hasil Penelitian, Data diolah 2020)

Tabel di atas menunjukkan bahwa hasil uji model -2 Log Likelihood sebesar 283,975 dari koefisien determinasi yang diperoleh dari nilai Nagelkerke $R$ Square sebesar 0,492 (49,2\%) dengan nilai Cox \& Snell R Square sebesar $0,368(36,8 \%)$ yang berarti bahwa variabel dependen yang dapat dijelaskan oleh variabel independen sebesar 49,2\% dan sisanya dijelaskan oleh faktor-faktor lain diluar model penelitian sebesar 50,8\%. (Ghozali, 2016:329).

\section{Matriks klasifikasi}

Matriks klarifikasi memprediksi kekuatan dari model regresi dalam kualitas audit perusahaan dari KAP Big Four dan non Big Four seperti yang dilihat dalam tabel berikut :

\section{Classification Table ${ }^{a}$}

\begin{tabular}{|c|c|c|c|c|c|}
\hline & \multirow{3}{*}{\multicolumn{2}{|c|}{ Observed }} & \multicolumn{3}{|l|}{ Predicted } \\
\hline & & & \multicolumn{2}{|c|}{ Kualitas audit } & \multirow[b]{2}{*}{ Percentage Correct } \\
\hline & & & non big four & big four & \\
\hline \multirow[t]{2}{*}{ Step 1} & \multirow[t]{2}{*}{ Kualitas audit } & non big four & 137 & 35 & 79,7 \\
\hline & & big four & 44 & 94 & 68,1 \\
\hline
\end{tabular}

Jurnal Ilmiah Akuntansi dan Ekonomi Volume. 6 Nomor. 1, Februari 2021 Hal. 115 


\begin{tabular}{|l|l|l|}
\hline Overall Percentage & & 74,5 \\
\hline a. The cut value is, 500 & & \\
\hline
\end{tabular}

(Sumber: Hasil Penelitian, Data diolah 2020)

Berdasarkan tabel diatas, menunjukkan kekuatan prediksi dari model regresi untuk memprediksi kemungkinan perusahaan melihat kualitas audit dengan KAP non Big Four sebesar 79,7\%. Hal ini menunjukkan hasil observasi dengan menggunakan model regresi ini yang diprediksi akan melihat kualitas audit dengan KAP non Big Four ditambah dengan Big Four total 172 perusahaan adalah 79,7\% yang hasilnnya dilihat dengan KAP non Big Four. Sedangkan kekuatan prediksi dari model regresi untuk memprediksi kemungkinan perusahaan melihat kualitas audit dengan KAP Big Four sebesar 68,1\%. Hal ini menunjukkan bahwa model regresi yang digunakan ada sebanyak 138 perusahaan yang melihat dengan KAP Big Four.

\section{Model regresi linear logostik yang terbentuk}

Analisis yang digunakan dalam penelitian ini adalah analisis regresi logistik (logistic regression), yaitu dengan melihat pengaruh Fee audit, ukuran perusahaan dan audit tenure terhadap kualitas audit pada perusahaan jasa di Bursa Efek Indonesia (BEI). Model linier regresi logistik (logistic regression)dalam penelitian ini dapat dilihat pada tabel dibawah:

\section{Variables in the Equation}

\begin{tabular}{|l|l|r|r|r|r|r|}
\hline \multicolumn{2}{|c|}{} & & & & & \\
\hline \multirow{3}{*}{ Step 1 ${ }^{\mathrm{a}}$} & Fee audit &, 908 &, 180 & 25,605 & 1 &, 000 \\
\cline { 2 - 7 } & ukuran perusahaan &, 105 &, 166 &, 398 & 1 &, 528 \\
\cline { 2 - 7 } & audit tenur &, 216 &, 110 & 3,892 & 1 &, 049 \\
\cline { 2 - 7 } & Constant & $-24,045$ & 3,245 & 54,891 & 1 &, 000 \\
\hline
\end{tabular}

a. Variable(s) entered on step 1: Fee audit, ukuran perusahaan, audit tenur.

(Sumber : Hasil Penelitian, Data diolah 2020)

\section{Pengujian secara parsial}

Pengujian hipotesis dilakukan dengan cara membandingkan antara tingkat signifikansi (sig) dengan signifikansi $(\alpha)=5 \%$.

Berdasarkan tabel diatas maka model regresi logistik yang diperoleh adalah sebagai berikut :

Logit_KA $=-24,045+0,908 \beta 1 \times 1+0,105 \beta 2 \times 2+0,216 \beta 3 \times 3+e$

Keterangan :

Logit KA

$\mathrm{X1}$

$\mathrm{X} 2$

$\mathrm{X3}$

阝 1-3

e

Variabel Fee Audit memiliki nilai statistik wald sebesar 25,605 sedangkan
: Kualitas audit

: Fee Audit

: Ukuran Perusahaan Klien

: Audit Tenure

: Koefisien Regresi

: Eror

Jurnal Ilmiah Akuntansi dan Ekonomi Volume. 6 Nomor. 1, Februari 2021 Hal. 116 
berdasarkan Tabel Chi-Square dengan tingkat signifikansi 0,05 dan tingkat kebebasan sebesar 1 diperoleh hasil 10,419. Nilai koefisien variabel ini sebesar 0,908 yang berarti setiap kenaikan satu satuan pada fee audit maka kesempatan perusahaan dalam mendapatkan audit yang berkualitas akan meningkat sebesar 0,908 satuan dengan asumsi variabel bebas bernilai 0 . Nilai signifikansi fee audit menghasilkan nilai yang lebih kecil dari 0,05 yaitu memiliki nilai sebesar 0,000. Hal ini menunjukkan hipotesis 1 diterima yang menyatakan bahwa fee audit berpengaruh signifikan terhadap kualitas audit. Hal ini berarti bahwa fee audit memiliki pengaruh yang signifikan terhadap kualitas audit.

Variabel ukuran perusahaan memiliki nilai statistik wald sebesar 0,398 sedangkan berdasarkan Tabel Chi-Square dengan tingkat signifikansi 0,05 dan tingkat kebebasan sebesar 1 diperoleh hasil 10,419. Nilai koefisien ukuan perusahaan adalah sebesar 0,105 yang berarti setiap kenaikan satu satuan pada ukuran perusahan dalam mendapatkan audit yang berkualitas akan menurun sebesar 0,105 satuan dengan asumsi variabel bebas lainnya dianggap konstan. Nilai signifikan ukuran perusahaan menghasilkan nilai yang lebih besar dari 0,05 yaitu memiliki nilai sebesar 0,528. Hal ini menunjukkan hipotesis 2 ditolak. Hal ini berarti bahwa ukuran perusahaan tidak berpengaruh yang signifikan terhadap kualitas audit.

Variabel audit tenure memiliki nilai statistik wald sebesar 3,892 sedangkan berdasarkan Tabel Chi-Square dengan tingkat signifikansi 0,05 dan tingkat kebebasan sebesar 1 diperoleh hasil 10,419. Nilai koefisien audit tenure adalah sebesar 0,216 yang berarti setiap kenaikan satu satuan pada audit tenure maka kesempatan perusahaan dalam mendapatkan audit yang berkualitas akan menurun sebesar 0,216 satuan dengan asumsi variabel bebas lainnya dianggap konstan. Nilai signifikan audit tenure menghasilkan nilai yang lebih besar dari 0,05 yaitu memiliki nilai sebesar 0,049 . Hal ini menunjukkan hipotesis 3 diterima yang menyatakan bahwa audit tenure berpengaruh signifikan terhadap kualitas audit. Hal ini berarti bahwa audit tenure memiliki pengaruh yang signifikan terhadap kualitas audit.

\section{Kesimpulan}

\section{KESIMPULAN DAN SARAN}

\section{Pengujian secara parsial}

\section{Pengaruh Fee Audit Terhadap Kualitas Audit}

Hasil uji koefisien regresi logistik menunjukkan bahwa koefisien regresi bernilai sebesar 0,908 dengan tingkat signifikansi sebesar 0,000 yang lebih kecil dari nilai koefisien $\alpha$ sebesar 5\% (0,05), hal ini menunjukkan bahwa hipotesis pertama diterima. Biaya audit yang lebih tinggi biasanya akan meningkatkan kualitas audit, hal ini disebabkan karena dalam menetapkan imbalan fee audit, Akuntan Publik harus memperhatikan hal-hal berikut yaitu : kebutuhan klien, tugas dan tanggung jawab menurut hukum, independensi, tingkat keahlian dan tanggung jawab yang melekat pada pekerjaan yang dilakukan, serta tingkat kompleksitas pekerjaan dan basis penetapan fee yang disepakati.

Jurnal Ilmiah Akuntansi dan Ekonomi Volume. 6 Nomor. 1, Februari 2021 Hal. 117 


\section{Pengaruh Ukuran Perusahaan Terhadap Kualitas Audit}

Hasil uji koefisien regresi logistik menunjukkan bahwa koefisien regresi bernilai sebesar 0,105 dengan tingkat signifikansi sebesar 0,528 yang lebih besar dari nilai koefisien $\alpha$ sebesar 5\% $(0,05)$, hal ini menunjukkan bahwa hipotesis kedua ini ditolak dan menunjukkan bahwa ukuran perusahaan tidak berpengaruh secara signifikan terhadap kualitas audit. Hal ini disebabkan karena Besar kecilnya perusahaan belum tentu memiliki manajemen yang berpengalaman dan sistem pengendalian intern yang baik untuk menghasilkan audit yang lebih berkualitas dibandingkan perusahaan kecil, Kemungkinan perusahaan besar yang melaporkan laba dengan tujuan untuk menarik kepercayaan investor.

\section{Pengaruh Audit Tenure Terhadap Kualitas Audit}

Hasil uji koefisien regresi logistik menunjukkan bahwa koefisien regresi bernilai sebesar 0,216 dengan tingkat signifikansi sebesar 0,049 yang lebih kecil dari nilai koefisien $\alpha$ sebesar 5\% $(0,05)$, hal ini menunjukkan bahwa hipotesis ketiga diterima dan menunjukkan bahwa audit tenure berpengaruh secara signifikan terhadap kualitas audit. Hal ini menunjukkan bahwa masa perikatan KAP menjamin bahwa hasil yang diperoleh audit akan berkualitas, karena Hubungan yang singkat antara auditor dan kliennya, bisa menyebabkan dampak untuk seorang auditor dalam mendapatakan informasi beserta bukti-bukti yang terbatas, karena hal ini bisa menyebabkan adanya potensi salah saji yang tidak terdeteksi oleh auditor. Oleh karena itu dibutuhkan hubungan dalam jangka waktu yang sangat panjang agar auditor lebih dapat memahami bisnis klien serta risiko klien.

\section{Saran}

1. Penelitian ini hanya menggunakan periode penelitian selama 5 tahun yaitu 2014-2018 tidak bisa generalisasi karena penelitian ini hanya dapat mencerminkan untuk periode penelitian ini saja dan tidak dapat mencerminkan untuk periode tahun sebelum atau sesudah penelitian.

2. Beberapa perusahaan tidak menyajikan annual report besrta laporan keuangan secara rinci mengenai data yang akan digunakan untuk melakukan pengukuran variabel, sehingga peneliti mengalami kesulitan saat melakukan pengimputan data.

3. Ukuran perusahaan yang di prosikan dengan nilai total asset yang tidak pengaruh terhadap kualitas audit, peneliti selajutnnya disarankan unuk menggunakan proksi lain seperti total penjualan, jumlah laba, beban pajak dan proksi lain yang lebih akurat

4. Penelitian ini hanya menggunakan obyek penelitian dari perusahaan manufaktur, sehingga hasil dari penelitian ini mungkin tidak bisa digeneralisasi pada sektor perusahaan yang lain.

5. Peneliti diharapkan dapat menggunakan alternatif tanggal publikasi laporan keuangan yang lain agar tidak bergantung pada tanggal publikasi yang tersedia di situs resmi BEI.

6. Peneliti hanya menggunakan periode penelitian selama 5 tahun. Peneliti

Jurnal Ilmiah Akuntansi dan Ekonomi Volume. 6 Nomor. 1, Februari 2021 Hal. 118 
selanjutnya diharapkan memperpanjang waktu penelitian nya sehingga dapat melihat aduit tenure dilakukan untuk mencegah terjadinya kecurangan karena kedekatan antara auditor dan klien.

7. Peneliti selanjutnya diharapkan untuk memperluas sampel penelitian d

8. engan menggunakan sampel perusahaan dibidang lainnya, tidak hanya menguji perusahaan manufaktur yang terdaftar di BEI.

9. Peneliti selanjutnya diharapkan untuk menambah variabel independen lainnya seperti spesialisasi auditor, rotasi auditor, reputasi audit dan independensi auditor agar mampu menjelaskan kualitas audit lebih baik lagi.

\section{DAFTAR PUSTAKA}

\section{Sumber Buku :}

Agoes, Sukrisno. 2016. Auditing Petunjuk Praktis Pemeriksaan Akuntan oleh Kantor Akuntan Publik. Edisi 4. Jakarta: Salemba Empat.

Amir Suhaib,et.all 2011. "Auditor-Client Relationship, and Audit Quality"; the Effects Of Long-Term Auditor-Client Relationship On Audit Quality, In Small and Medium-Sized Entities (SMEs).1st Edition LAP Lambert Gmbh \& Co.KG, Germany.

Arens,Alvin.,Randal J.Elder, Mark S.Beasley.2010. Jilid I, Edisi Ke Dua belas.Auditing dan Jasa Assurance, alih bahasa oleh Herman Wibowo. Jakarta: Erlangga.

Arens, Alvin., , Randal J. Elder, Mark S. Beasley, 2012, Auditing and. Assurance Services: An Integrated Approach, 1.3th Edition, Pearson. Prentice Hall.

Ghozali, I. (2009). Aplikasi Analisis Multivariate Dengan Program SPSS.Jakarta: Badan Penerbit Universitas Diponegoro.

Ghozali, Imam. 2016. Aplikasi Analisis Multivariete Dengan Program IBM SPSS 23 (Edisi 8). Cetakan ke VIII. Semarang : Badan Penerbit Universitas Diponegoro.

Ghozali, Imam. 2012. Aplikasi Analisis Multivariate dengan Program IBM SPSS 20. Semarang: Badan Penerbit - Universitas Diponegoro.

Hartono, Jogiyanto. 2015. Teori Portofolio dan Analisis Investasi Edisi Kesepuluh. Yogyakarta : BPFE.

Menteri Keuangan. Keputusan Menteri Keuangan Nomor:359/KMK.06/2003 Tentang "Jasa Akuntan Publik" dan Perubahan atas Keputusan Menteri Keuangan Nomor:423/KMK.06/2002, Jakarta, 2003.

Menteri Keuangan. Peraturan Menteri Keuangan Nomor17/PMK.01/2008 Tentang "Jasa Akuntan Publik", Jakarta, 2003.

Mulyadi. 2009. Auditing. Edisi 6. Buku 1. Salemba Empat. Jakarta.

Mulyadi, 2013. Auditig, Jakarta : Salemba Empat.

Mulyadi. (2014). Auditing Buku 1 (6th Ed.). Jakarta: Salemba Empat.

Nugrahanti, Yuvina. (2014). "Pengaruh Audit Tenure, Spesialisasi Kantor Akuntan

Publik dan Ukuran Perusahaan Terhadap Kualitas Audit". Universitas

Diponegoro Semarang.

Standar Profesional Akuntan Publik (SPAP). 2011. PSA No.04 SA Seksi 230.

Jurnal Ilmiah Akuntansi dan Ekonomi Volume. 6 Nomor. 1, Februari 2021 Hal. 119 
InstitutAkuntan Publik Indonesia. Jakarta.

Sekaran, Uma. 2011. Research Methods For Business (Metode Penelitian Untuk Bisnis).Jakarta: Salemba Empat.

Siti Kurnia Rahayu dan Ely Suhayati.2013. Auditing : Konsep Dasar dan Pedoman Pemerikasaan Akuntan Publik, Edisi Pertama, Penerbit Graha Ilmu Yogyakarta.

Wing Wahyu Winarno. (2011). Analisis Ekonometrika dan Statistika dengan Eviews, Edisi Ketiga. Yogyakarta : Unit Penerbit dan Percetakan (UPP STIM YKPN).

\section{Sumber Jurnal :}

Adeniyi, Segun Idowu., dan Gabriel, Mieseigha. 2013. "Audit Tenure: an Assessment of its Effects on Audit Quality in Nigeria”.International Journal of Academic Research in Accounting, Finance and Management Sciences Vol. 3, No. 3, pp. 275-283, ISSN: 2225-8329.

Agusti dan Pertiwi. 2013. Pengaruh Kompetensi, Independensi dan Profesionalisme

Terhadap Kualitas Audit (Studi Empiris Pada KantorAkuntan Publik SeSumatera).Jurnal Ekonomi Volume 21.

Al-Thuneibat, A.A., Al Issa, R.T.I. and Baker, R.A.A. 2011, "Do Audit Tenure and FirmSize Contribute to Audit Quality”. Managerial Auditing Journal, Vol. 26, pp. 317-334.

Amalia , Rizki Fitri. 2017. Pengaruh Due Proffesional Care, Time Budget Pressure dan Risiko Audit terhadap Kualita Audit. Jurnal Akuntansi dan Binis.

Darya, K., dan Puspitasari, S. A. 2012. "Reputasi KAP, Auditor Tenure, Ukuran Perusahaan Klien dan Kualitas Audit (Studi pada perusahaan LQ 45 Indonesia)". Vol.3, No.2, pp:113-127.

De Angelo, L.E. 1981. Auditor Size and and Audit Quality. Agustus. P. 113127.Journal of Accounting and Economics. (Desember) pp. 183-199.

Febriyanti, dan Mertha. 2014. Pengaruh Masa Perikatan Audit, Rotasi KAP, Ukuran Perusahaan Klien, dan Ukuran KAP Pada Kualitas Audit. E-Jurnal Akuntansi Universitas Udayana, Vol.7, No.2, Hal: 503-518.

Fernando, G. D.,Ahmed M., dan Randal J. E. 2010. Audit quality attributes, client size and cost of equity capital. "Review of Accounting and Finance, Vol. 9, No. 4, pp. 363-381.

Hasbullah, dkk. (2014). Pengaruh Keahlian Audit, Kompleksitas Tugas dan Etika Profesi terhadap Kualitas Audit. E-Journal S1 Ak Vol. 2 No.1

Hartadi, Bambang. (2012). Pengaruh Fee Audit, Rotasi KAP, Reputasi Auditor Terhadap Kualitas Audit di Bursa Efek Indonesia. Jurnal Ekonomi dan Keuangan,Vol.16, No.1.

Jensen, Michael C, and William H. Meckling, 1976, Theory of the Firm: Managerial Behavior, Agency Costs and Ownership Structure, Journal of Financial Economics, October 1976, Vol. 3, No. 4, pp. 305-360.

Khairunisa, A.A., \& Yustrianthe, R. H. (2015). Kajian Empiris Faktor-faktor yang Memengaruhi Kualitas Audit. Jurnal Ilmiah Wahana Akuntansi, Vol. 10, No. 1, hal 1-23.

Kurniasih, Margi dan Abdul Rohman. (2014). "Pengaruh Audit Fee Audit, Audit Tenure, dan Rotasi Audit Terhadap Kualitas Audit”.Diponegoro Journal Of Accounting Volume 3, Nomor 3, Tahun 2014.

Jurnal Ilmiah Akuntansi dan Ekonomi Volume. 6 Nomor. 1, Februari 2021 Hal. 120 
Kusumawardani, Diah dan Akhmad Riduwan. 2017. Pengaruh Independensi, Audit Fee, dan Objektivitas Terhadap Kualitas Audi.,Jurnal Ilmu dan Riset Akuntansi. Vol.6(1).

Umi Salamah. 2019. "Pengaruh Audit Tenure, ukuran KAP dan Spesialisasi auditor Pada Kualitas Audit”. E-Jurnal Akuntansi Universitas Satya Negara Indonesia.

Nindita, C dan Siregar, S.V. 2012. Analisis Pengaruh Ukuran Kantor Akuntan Publik Terhadap Kualitas Audit di Indonesia. Jurnal Akuntansi dan Keuangan, Vol.14, No.2, pp.91-103.

Paramita, Ni Ketut Ayu dan Ni Made Yenni Latrini. 2015. Pengaruh Ukuran Perusahaan, Umur Publikasi, Masa Perikatan Audit, Pergantian Manajemen Pada Kualitas Audit. E-Jurnal Akuntansi Universitas Udayana 13.1(2015): 142-156. ISSN: 2303-8556

Panjaitan, Clinton Marshal dan Anis Chariri. 2014. "Pengaruh Tenure, Ukuran KAP dan Spesialisasi Auditor Terhadap Kualitas Audit". Diponegoro Journal of Accounting.Vol.3, No.3.

Sinaga, M. T. Daud dan Ghozali, "Analisis Pengaruh Audit Tenure, Ukuran KAP danUkuran Perusahaan Klien Terhadap Kualitas Audit”, 2011

\section{Sumber Riset :}

Andriani, Ninik dan Nursiam. 2017. "Pengaruh Fee Audit, Audit Tenure, Rotasi Audit dan Reputasi Auditor terhadap Kualitas Audit (Studi Empiris pada Perusahaan Manufaktur yang Terdaftar di Bursa Efek Indonesia Tahun 2013-2015)”. Riset Akuntansi dan Keuangan Indonesia, 3(I).

\section{Sumber Skripsi :}

Kharismatuti, Norma. 2012.Pengaruh Kompetensi dan Independensi Terhadap Kualitas Audit dengan Etika Auditor sebagai Variabel Moderasi. SKRIPSI Universitas Diponogoro, Semarang.

Ramdani, Rifki. 2016. "Pengaruh Fee Audit, Audit Tenure, Rotasi Audit dan Ukuran Perusahaan Klien terhadap Kualitas Audit (Studi pada Sektor Keuangan yang Terdaftardi BEI Periode 2012-2014)". Skripsi. Jakarta: Fakultas Ekonomi dan Bisnis, Universitas Islam Negeri Syarif Hidayatullah.

\section{Sumber Website :}

http://www.idx.com

Jurnal Ilmiah Akuntansi dan Ekonomi Volume. 6 Nomor. 1, Februari 2021 Hal. 121 